ARTICLE

\title{
Passive acoustic monitoring of the bottlenose dolphin Tursiops truncatus to determine continuous presence in Ensenada de La Paz, Mexico
}

Monitoreo acústico pasivo del delfín nariz de botella Tursiops truncatus para determinar su presencia continua en la Ensenada de La Paz, México

\author{
Marco FW Gauger ${ }^{1}$, Javier Caraveo-Patiño ${ }^{1}$ and Eduardo Romero-Vivas ${ }^{1^{*}}$ \\ ${ }^{1}$ Centro de Investigaciones Biológicas del Noroeste (CIBNOR), Avenida IPN 195, Playa Palo de Santa Rita Sur, C.P. 23096 La Paz, \\ Baja California Sur, Mexico \\ *Corresponding author: evivas@cibnor.mx
}

\begin{abstract}
Resumen.- El delfín nariz de botella (Tursiops truncatus) es una especie centinela que refleja la salud del ecosistema. En el Golfo de California, se encuentran delfines nariz de botella en áreas que se traslapan con áreas de actividad humana, como por ejemplo en la Ensenada de La Paz. Un sistema de grabación acústica diseñado para tal fin se colocó a la entrada a la Ensenada de La Paz, a profundidad media $(2,0 \mathrm{~m}$ ), para grabar silbidos de delfines nariz de botella entre junio y noviembre del 2017 ( 8 despliegues; 293 horas). Los silbidos, que son indicadores de presencia de delfines nariz de botella, fueron agrupados por intervalos para adquirir encuentros acústicos. Se analizaron los encuentros acústicos para inferir la continuidad de la presencia de los animales y verificar si existía diferencia estadística significativa entre campañas, entre el día y la noche, y entre horas. Se registraron silbidos durante todas las campañas y se evidenció su presencia nocturna en la ensenada. La mayoría de los encuentros fueron registrados en las primeras dos campañas en junio y julio. Estos fueron agrupados ('Jun-Jul') y comparados con el resto de las campañas de septiembre a noviembre ('Sep.-Nov'), siendo los encuentros acústicos más frecuentes en el primer grupo. Las pruebas estadísticas mostraron diferencias significativas entre día y noche (más alto en la noche), pero no entre horas. Con datos acústicos se pudo confirmar la presencia continua de delfines nariz de botella en la Ensenada de La Paz, lo que subraya la importancia de esta área de estudio para la populación. Este estudio inicial resalta también la utilidad del monitoreo acústico de largo plazo para propósitos de manejo y conservación.
\end{abstract}

Palabras clave: Bioacústica, silbidos, presencia día/noche, laguna costera

\begin{abstract}
Bottlenose dolphins (Tursiops truncatus) are ecosystem sentinels. In the Gulf of California, Mexico, they are found in areas that overlap with human activities, as in the case of the Ensenada de La Paz lagoon. A custom-made recorder -moored at medium depth $(2.0 \mathrm{~m})$ in the entrance to the lagoon- recorded acoustic data from June to November 2017 ( 8 deployments; $293 \mathrm{~h}$ ). Whistles -an indicative of bottlenose dolphin presences- were pooled over time to acquire acoustic encounters, which were analysed to infer continuity of animal presence and test for statistically significant differences between deployments, day and night, and hours. Whistles were recorded during all deployments and evidenced night-time presence of bottlenose dolphins in the lagoon. Significant differences of acoustic encounters were observed between 'Jun-Jul' and 'Sep-Nov'. Acoustic encounters were higher at night but were not different at an hourly level. Acoustical data proved the continuous presence of bottlenose dolphins, highlighting the importance of the Ensenada de La Paz for their population. This initial study highlights the usefulness of long-term passive acoustic monitoring to inform stake holders involved in management and conservation plans.
\end{abstract}

Key words: Bioacoustics, whistle, day/night presence, coastal lagoon

\section{INTRODUCTION}

The life-history of the common bottlenose dolphin (Tursiops truncatus Montagu, 1821) makes the species sensitive to environmental and anthropogenic stressors (Bossart 2011, Todd et al. 2015, Altherr \& Hodgins 2018), which designate it as a putative "environmental sentinel" of ecosystem health (Wells et al. 2004, Bossart 2011). Environmental impact assessment (EIA) and studies of marine protected areas of coastal and riverine ecosystems monitor the distribution and presence of bottlenose dolphins, as well as of other small cetaceans (Hoyt 2012, BSH 2013, Castellote et al. 2015).
Bottlenose dolphins are commonly found in coastal zones where they feed, socialise, rest, and nurse. Their occurrence depends on prey availability, shelter, and suitability for reproduction. The spatial-temporal availability of prey influences if their presence is continuous associated to random feeding events, or peaks due to seasonal migrations (Torres \& Read 2009, MarcínMedina 2010, Fury \& Harrison 2011). Several delphinid species including the bottlenose dolphin are known to forage during night and twilight hours when prey is more accessible to them compared to other predators that depend only on visual cues (Carlström 2005, Hammerschlag et al. 
2010, Castellote et al. 2015). Higher acoustical detections of echolocation clicks at night are commonly interpreted as increased feeding or related to migrations to a specific feeding hotspot at high sea (Benoit-Bird \& Au 2003, Au et al. 2013, Hodge et al. 2013, Baumann-Pickering et al. 2015).

Knowledge of night-time habitat use is often missing since it is difficult to assess using visual observations, which provide good quality data but costly, and they depend on favourable weather and light conditions (Buckland et al. 2001). This technique has short temporal resolution. If the probability of occurrence depends on prey or predator presence and accessibility, which in turn may change over the course of the day (Rooker \& Dennis 1991, Hammerschlag et al. 2010), habitat use might not be correctly assessed with this technique. Moreover, anthropogenic activities during the assessment such as boat traffic and night lights might also affect animal presence (Acevedo 1991a, La Manna et al. 2014, Heiler et al. 2016, Zapata et al. 2019).

Acoustic techniques are required in EIAs of coastal areas to close information gaps and to study continuous presence (BSH 2013, Castellote et al. 2015, Wang et al. 2015). These methodologies allow continuous sampling under unfavourable conditions, and in remote areas at relatively low costs. However, uncertainties are due to technical and biological factors. Detection probability depends on the equipment sensitivity, sound pressure level at the source, and level and type of ambient background noises (Versluis et al. 2000, Zimmer 2011). Biological factors influencing detections are animal behaviour, activity pattern, group composition, and size (Therrien et al. 2012, King \& Janik 2015, Heiler et al. 2016). All these factors impact identification at species level, which may lead to increased effort to process data correctly (Oswald et al. 2003).

Acoustic techniques for bottlenose dolphins can focus either on highly directional clicks or on whistles. Dolphins emit continuous series of clicks between 60 and $200 \mathrm{kHz}$ to navigate and detect prey in a radius from 70 to $173 \mathrm{~m}$ (Au et al. 2007). Up to date, most research on dolphin occurrence has been based on echolocation click detection. Particularly, click rates have been used for impact assessment studies of coastal and offshore infrastructures (oil rigs, offshore windfarms or ports). Click detection has been also used in studies looking into how geographical differences in feeding habits influenced the observed diurnal presence (e.g., Au et al. 2013, Castellote et al. 2015, Wang et al. 2015). Click emission rate is often used to highlight feeding rates, which are pooled over minutes, hours, and days (Carlström 2005).
Whistles, on the other hand, are omnidirectional narrowband sounds within a frequency range of 1.2-35 kHz (MayCollado \& Wartzok 2008, Janik \& Sayigh 2013). They indicate social intra-specific communication, such as group cohesion, coordinated foraging and mother-calf interactions (Janik \& Sayigh 2013, King \& Janik 2015, Heiler et al. 2016). Few studies on dolphin occurrence have analysed only whistles or both clicks and whistles. The latter indicated that clicks and whistles do not necessarily show the same diurnal patterns (Hodge et al. 2013, Baumann-Pickering et al. 2015, Caruso et al. 2017) since both relate to different behavioural states. Dataloggers are generally programmed to detect either clicks or whistles although some studies may record both types of signals. Because both signals have different intensity, adjusting for one of them might result in either clipping or losing the other (Bazúa-Duran \& HerreraHernández 2007). Due to their omnidirectional propagation and higher theoretical detection range (Jensen et al. 2009, 2012), whistle detection techniques were selected to assess the presence of bottlenose dolphins. Whistles (or clicks) can be grouped together into acoustic encounters if they have a lag between two acoustic events smaller than $10 \mathrm{~min}$ and are comparable to sighting events (Carlström 2005).

Ensenada de La Paz is a coastal lagoon in Baja California Sur, Mexico with mangrove vegetation serving as a nursery for many fish and bird species (López-Rasgado et al. 2012, Verdugo-Díaz et al. 2017). The bottlenose dolphin is the only known odontocete frequenting the lagoon (Acevedo 1991b, Marcín-Medina 1997, 2010; Salinas-Zacarías 2005) although other species occur in adjacent waters (Salvadeo et al. 2009, Pardo et al. 2013). Bottlenose dolphin presence in this area has been reported to vary seasonally, a higher presence has been found during spring and summer, especially from May to August (Acevedo 1991b, MarcínMedina 1997, 2010; Salinas-Zacarías 2005).

This study assumed that bottlenose dolphin behaviour was not constrained to a circadian rhythm. Thus, its hypothesis is that their whistles can be detected continuously in Ensenada de La Paz during both day and night-time. To test this hypothesis, a static acoustic monitoring (SAM) station was deployed in the entrance to Ensenada de $\mathrm{La}$ Paz. The results provide new information in terms of the continuity of bottlenose dolphin occurrence within this area and help to understand the importance of this lagoon for this species. 


\section{MATERIALS AND METHODS}

\section{STUDY AREA}

Ensenada de La Paz, a coastal lagoon in the southern edge of the Bahía de La Paz, Baja California Sur, Mexico (Fig. 1 ), is between 1 and $3 \mathrm{~m}$ deep and comprises an area of 45 $\mathrm{km}^{2}$ connected to the bay by a $6-\mathrm{km}$ long and $1-\mathrm{km}$ wide channel (5 to $10 \mathrm{~m}$ deep, Fig. 1c, Copernicus Sentinel 2 data 2018, processed by ESA). The channel entrance is a shallow area $1.5 \mathrm{~m}$ deep at high tide and almost falls dry during low tide (Fig. 1c).

\section{RECORDER AUDIO FILES}

A custom-made sound recorder was moored at medium depth in the entrance to Ensenada de La Paz (ELAP; 410 $\mathrm{m}$ from the coast, water depth $3.5 \mathrm{~m}$, Fig. 1c). The entrance to the lagoon was chosen since all animals vocalising in the vicinity of the station should have been recorded, regardless of whether they remained there or passed this point on their way into the lagoon. Earlier studies have shown that both the entrance and the channel were frequently visited by bottlenose dolphins (Acevedo 1991b, Marcín-Medina 2010). The sandbank at the entrance, visible at low tide, might have caused the animals outside of the lagoon to be less likely recorded. The system was manufactured and assembled in the Centro de Investigaciones Biológicas del Noroeste (CIBNOR, Mexico). Its composition followed the simple hydrophone design (Joy et al. 2012) that was fitted to a plastic compartment containing a digital recorder and batteries. Specifications were chosen to record whistles of bottlenose dolphins (Tursiops truncatus) in shallow depth locations while enabling easy accessibility and low-cost maintenance. The recorder stores uncompressed audio files for up to $48 \mathrm{~h}(44.1 \mathrm{kHz}, 16-$ bit, 2 channels, Waveform Audio (WAV) format). Equipment had to be replaced due to losses and damages. The same hydrophone design was used in all settings but due to availability, the recorder (and its gain) changed (Table 1). The sensitivity of this hydrophone design (-193 dB re $1 \mathrm{~V} / \mu \mathrm{Pa})$ was tested by reciprocity (Bustamante et al. 2017). Data collection was attempted during eleven deployments from June to November 2017 (Table 1).

Audio files were screened visually in the frequency domain (Adobe Audition, version 3.0, spectrogram settings: 512 points fast Fourier transformed [FFT], Hanning window $50 \%$ overlap, display frame duration $4 \mathrm{~s}$, dynamic range -110 to $180 \mathrm{~dB}$ ). Audio files with different gains were corrected for comparison. Whistles —as indicators of bottlenose dolphin presence (May-Collado \& Wartzok 2008) — were grouped into the same acoustic encounter if
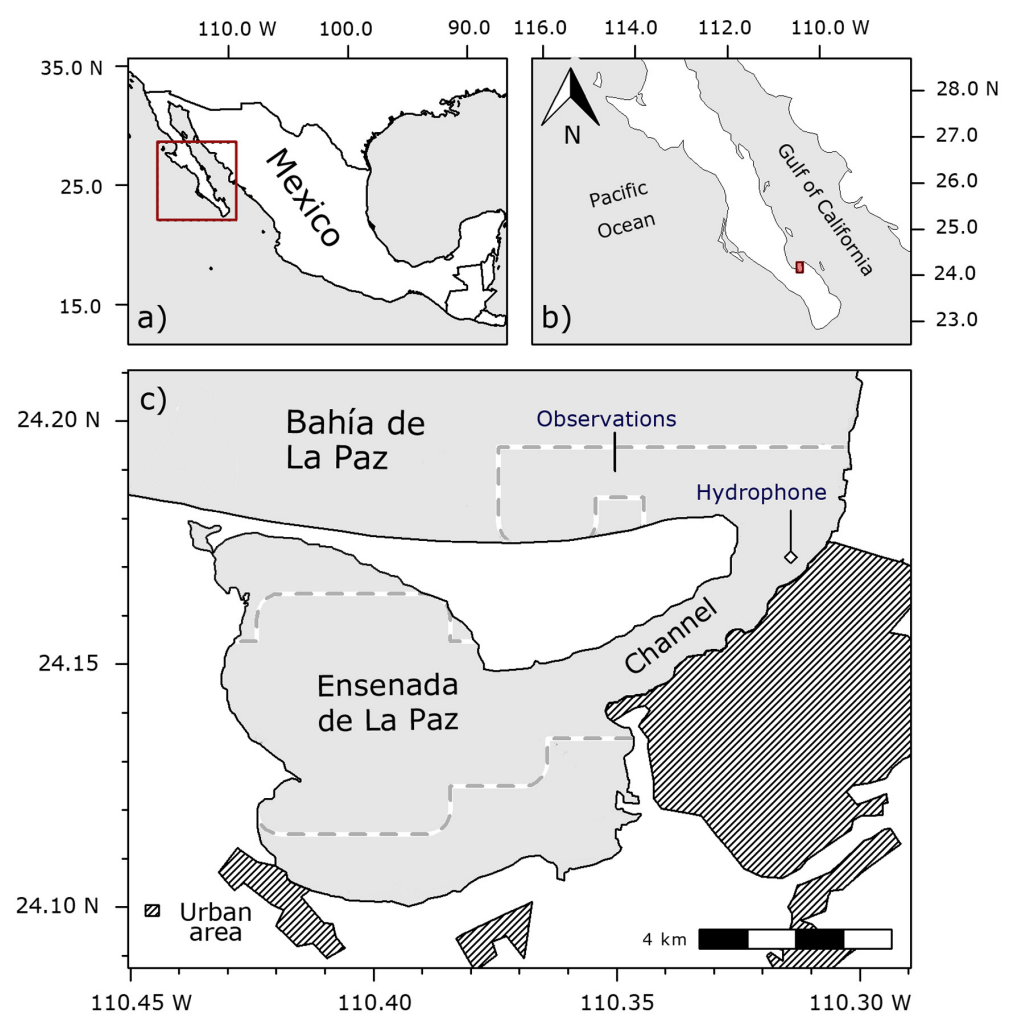

Figure 1. Study area with the position where acoustic equipment was moored and observations took place in Ensenada de La Paz (c), Baja California Sur (b), Mexico (a) / Área de estudio con la posición donde el equipo acústico fue colocado y donde ocurrieron las observaciones en la Ensenada de La Paz (c), Baja California Sur (b), México (a) 
Table 1. Acoustic recordings in the channel in front of Ensenada de La Paz, Baja California Sur, Mexico from June to November 2017 / Grabaciones acústicas en el canal frente a Ensenada de La Paz, Baja California Sur, México, entre junio y noviembre 2017

\begin{tabular}{cccccc}
\hline $\begin{array}{c}\text { Start date } \\
2017\end{array}$ & $\begin{array}{c}\text { Recorded } \\
\text { hours }\end{array}$ & $\begin{array}{c}\text { Hours } \\
\text { analysed }\end{array}$ & Encounter & $\begin{array}{c}\text { Total } \\
\text { encounter } \\
\text { duration (min) }\end{array}$ & Comment \\
\hline 21 Jun & 49.9 & 49.9 & 41 & 266.63 & \\
13 Jul & 49.9 & 30.4 & 33 & 503.63 & \\
13 Sep & 48.0 & 48.0 & 12 & 13.78 & \\
25 Sep & 7.8 & 7.8 & 1 & 0.02 & failure \\
05 Oct & - & - & - & - & failure \\
09 Oct & 47.9 & 47.9 & 14 & 10.02 & $*$ \\
16 Oct & - & - & - & - & failure \\
23 Oct & 43.6 & 43.6 & 16 & 7.32 & \\
30 Oct & 31.8 & 31.8 & 5 & 0.02 & \\
09.Nov & 33.7 & 27.1 & 11 & 16.48 & \\
27 Nov & - & - & - & - & failure \\
\hline
\end{tabular}

*change of recorder

the time between them was smaller than $10 \mathrm{~min}$ (Carlström 2005) assuming that they all belonged to one group of dolphins. If a silence of $10 \mathrm{~min}$ or more was recorded between whistles, either a new group of dolphins had arrived or the same group returned, and a new encounter started. Encounters of passing by animals might have a short duration while long ones might signal animals staying around the area. Therefore, if encounters lasted more than $10 \mathrm{~min}$ (encounter duration $\mathrm{ED}>10 \mathrm{~min}$ ) they were classified as long encounters whilst short ones (ED $<10 \mathrm{~min}$ ) may be as short as a single whistle.

\section{ObSERVATIONAL DATA}

Opportunistic visual data were collected during 16 experimental trips to Ensenada de La Paz and adjacent waters when the sound recorder was deployed or retrieved (Fig. 1). Surveys were conducted on board of a small fiberglass boat (approx. $7 \mathrm{~m}$ ) equipped with an outboard engine. The following observational data were collected by one or two observers: minute of first sighting, number of individuals, distance and heading. The surveys started in the morning around 09:00 $\mathrm{h}$ local time and lasted from 2 to 6 hours.

\footnotetext{
${ }^{1}<$ https://cran.r-project.org/web/packages/suncalc/index.html> ${ }^{2}<$ https://cran.r-project.org/web/packages/nortest/index.html> ${ }^{3}<$ https://cran.r-project.org/web/packages/car/index.html> ${ }^{4}<$ https://cran.r-project.org/web/packages/MASS/index.html> ${ }^{5}<$ https://cran.r-project.org/web/packages/WRS2/index.html> ${ }^{6}<$ https://cran.r-project.org/web/packages/signmedian.test/index.html> ${ }^{7}<$ https://cran.r-project.org/web/packages/lme4/index.html> ${ }^{8}<$ https://cran.r-project.org/web/packages/performance/index.html> ${ }^{9}<$ https://cran.r-project.org/web/packages/ggeffects/index.html>
}

\section{STATISTICAL ANALYSES}

Statistical analyses and graphical visualisations were completed using the free statistical software package $\mathrm{R}$ version 3.6.1 for Windows ( $\mathrm{R}$ Core Team 2017). Day was defined as the time between the moments in which the top edge of the sun appeared on the horizon until the sun disappeared below the horizon while night was the remaining time (suncalc package version 0.5.0) ${ }^{1}$. Encounter rates (ER: acoustic encounter per hour) and encounter duration (ED) deviated from normality and partly from homoscedasticity (Anderson-Darling normality test, 'nortest' package version 1.0-4'; ER: A= 43.32, $P<0.001$; ED: $\mathrm{A}=27.70, P<0.001$; Levene tests, 'car' package version 3.0-83; ER per deployment: d.f. $=7, P<0.001$, day and night: d.f. $=1, P=0.052$; ED per deployment: d.f. $=7$, $P<0.001$, day and night: d.f. $=1, P=0.032$ ). Here robust statistical procedures were applied since the sample was relatively low and removing outliers might have rendered it meaningless (Mair \& Wilcox 2019). M-estimator (Huber 1981) was applied to calculate sample average and standard deviation independently of the sample distribution and presence of outliers (package 'MASS' version 7.3-53) Welch's test (heteroscedastic one-way ANOVA for trimmed means, function t1 way of package 'WRS2' version $\left.1.1-0^{5}\right)$ with Lincon test as post-hoc procedure were applied to compare independent groups (Mair \& Wilcox 2019). Sign test was applied to compare day and night values of the averaged (M-estimator) encounter rate per deployment ('signmedian.test' package version 1.5.1) Additionally, generalised linear mixed-effect models ("glmer") were used to determine the difference between day and night presence (lme4 package version 1.1-23) ${ }^{7}$, as both daylength and effort differed between deployments. The model treated acoustic encounters as count data and assumed a Poisson error structure. Its repeated measure design considered that acoustic encounters per hour were dependent because they were recorded during consecutive day and night periods of the same deployment. Therefore, the model included 'deployment' as random effect. Fixed effects were 'day/night', 'SST' in ${ }^{\circ} \mathrm{C}$ (measured at deployment) to consider seasonal differences, and 'effort' in hours to consider different recording time. Variable selection followed a forward selection procedure where the random effect was included before including fixed effects. The most parsimonious model was chosen according to the lowest Akaike Information Criterion with a correction for small sample size (AICc) value and AICc weights since the number of datapoints was relatively small $(n=33)$. Variables were tested for multicollinearity and residual plots were visually inspected to detect possible deviation from homoscedasticity and normality ("performance" package for $\mathrm{R})^{8}$. Estimated marginal means (EMM, "ggeffects" package for R) ${ }^{9}$. 


\section{RESULTS}

Acoustic data were collected from eight out of eleven deployments. Three recordings failed or were discontinued (Sep $25^{\text {th }}$, Oct $5^{\text {th }}$ and $16^{\text {th }}$ and Nov $27^{\text {th }}$ ) due to failing batteries, leaking sealings or ruptured O-ring (Table 1). A total of $293 \mathrm{~h}$ of acoustic data were analysed from these deployments.

Logged whistles were attributed to 139 acoustic encounters (3,030 whistles, 5\% of overall effort, Fig. 2), which were recorded in 100 out of 293 analysed hours (34.1\%, Fig. 3). Twenty-two acoustic encounters - out of 139 - were long, lasting more than $10 \mathrm{~min}(15,8 \%)$. The four longest acoustic encounters $(37.2,70.9,107.5$ and $128.3 \mathrm{~min}$ ) comprised $42.0 \%$ of the total duration of bottlenose dolphin presence.

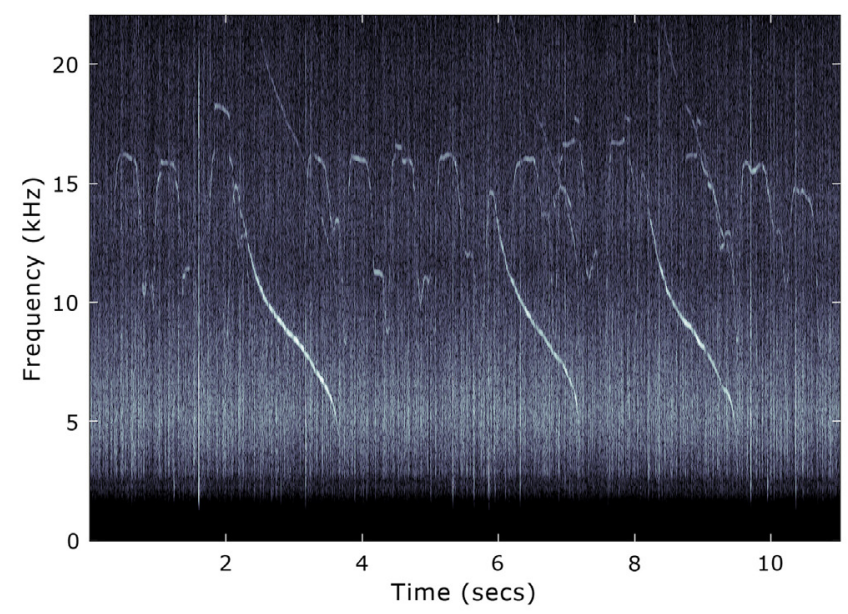

The number of acoustic encounters differed significantly between deployments (Welch test, $P<0.001$ ) with higher and significantly different values of 21 June and $13 \mathrm{Jul}$ than those from Sep $13^{\text {th }}$ and $25^{\text {th }}$, Oct $9^{\text {th }}$ and $30^{\text {th }}$ (Lincon test, $P<0.05)$. Consequently, the first two deployments were grouped since they had more acoustic encounters than the other six deployments from September to November $(P<0.001)$ (Table 1 and Fig. 4). The duration of acoustic encounters (ED) was also significantly higher in June and July ('Jun-Jul': averaged duration= $5.3 \mathrm{~min}$ ) than in September through November ('Sep-Nov': averaged duration $=0.0 \mathrm{~min}$; Welch test: $P=0.003$, Fig. 5). The whistle rate, i.e. number of whistles per duration of an encounter (whistles/ ED) was also higher in 'Jun-Jul' then in 'Sep-Nov' (Welch test: $P=0.0135$ ).

Figure 2. Recorded whistles of bottlenose dolphin in Ensenada de La Paz (Fast Fourier Transform (FFT) size: $\mathbf{5 1 2}$ samples, 50\% overlap, Hanning window) / Grabación de silbidos de delfín nariz de botella en la Ensenada de La Paz (tamaño FFT: 512 muestras, 50\% de superposición, ventana de Hanning)

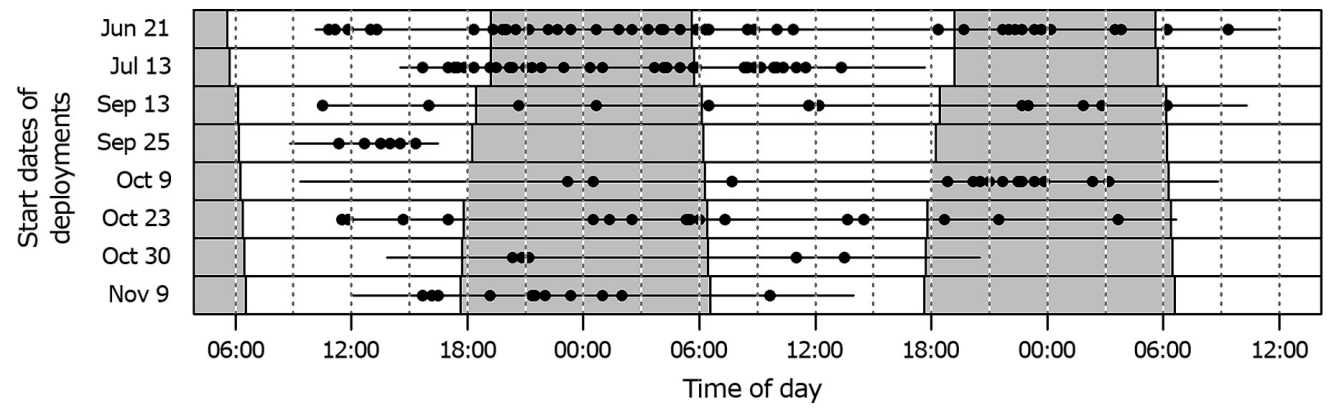

Figure 3. Effort (straight line) and acoustic encounters of bottlenose dolphins (circles) from June to November 2017 per deployment and time of the day / Esfuerzo (linea recta) y encuentros acústicos (círculos) entre junio y noviembre 2017 por campana y hora del día 


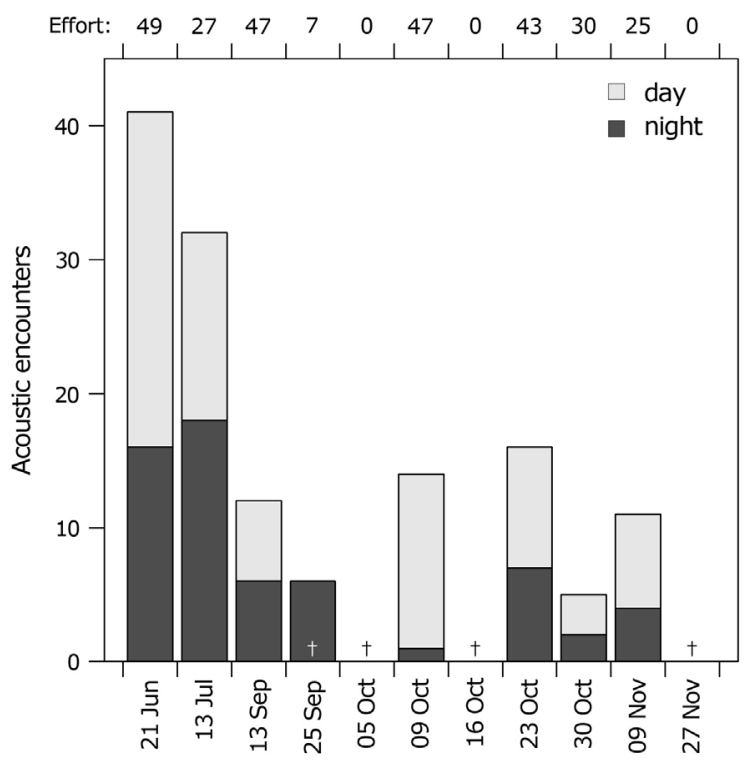

Figure 4. Acoustic encounters of bottlenose dolphins in the entrance to Ensenada de La Paz per deployment from June to November 2017 (cross: missing data, see Table 1) / Encuentros acústicos de delfines nariz de botella en la entrada a la Ensenada de La Paz entre junio y noviembre 2017 por campaña (cruz: datos incompletos, ver Tabla 1)

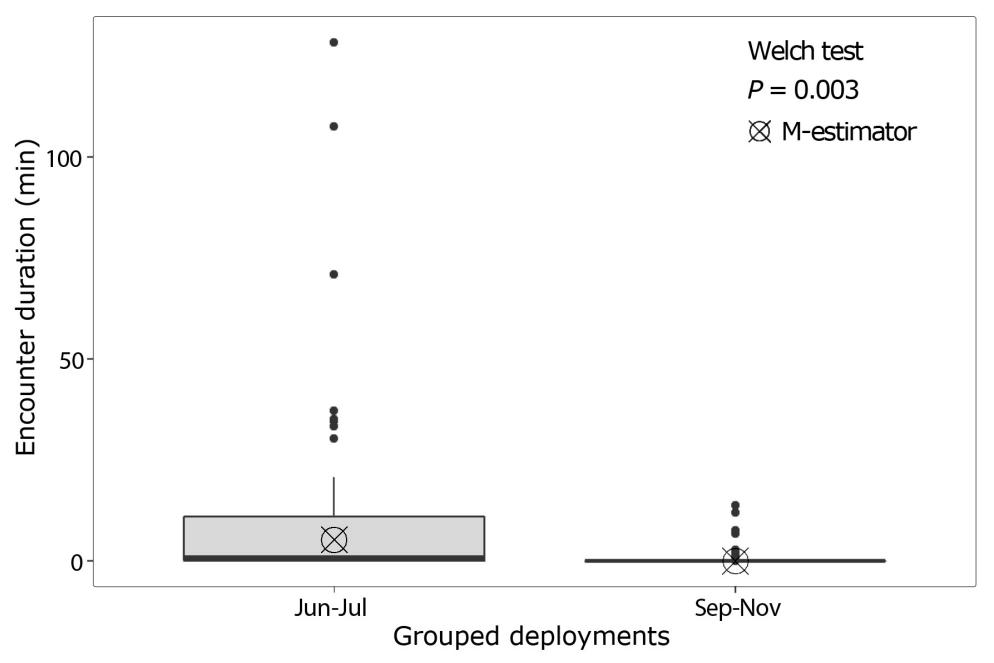

Figure 5. Box-Whisker plot with the duration of bottlenose dolphin acoustic encounters in the entrance to Ensenada de la Paz during 'Jun-Jul' and 'Sep- Nov' (Welch test and average, Huber's M-estimator) / Gráfica tipo "Box-Whisker" con la duración de los encuentros acústicos de delfines nariz de botella en la Ensenada de La Paz en 'Jun-Jul' y 'Sep-Nov' (prueba de Welch, promedio de Huber) 
The overall effort was higher in 'Sep-Nov' since six deployments were grouped compared to the 'June-July' group (outer rings Fig. 6). Day length was $2.1 \mathrm{~h}$ longer because the latter was reflected in the highest day effort (outer rings Fig. 6). The number of acoustic encounters at night was higher in 'Jun-Jul' than in 'Sep-Nov' (inner rings Fig. 6). Moreover, many long acoustic encounters ( $>10$ mins) were recorded in 'Jun-Jul' during day (10) and night (10). However, the sum of long acoustic encounter duration (ED) for that period was higher during day than night ( $\mathrm{n}=$ $20, W=22, P=0.035)$. On the other hand, 'Sep-Nov' had only two long acoustic encounters (Fig. 6).
Preliminary results indicated that no statistically significant difference was recorded between day and night presence of bottlenose dolphins (sign test, 'Jun-Jul': $P$ $=1.0$; 'Sep-Nov': $P=0.125)$. The most parsimonious generalised linear mixed model that considered SST, effort and day/night as fixed effects (model 08: $A I C c=141.07$, $A I C c$ weight $=0.56$, Table. 2 ) showed a large effect size of all fixed effects $\left(\left|\delta_{t}\right|>0.8\right.$, Table 3$)$. Interaction terms between fixed effects were dropped due to overfitting (Table 2). After accounting for seasonal and sampling effects (encounters increased with decreasing SST and increasing effort), encounters proved to be significantly higher at night than during day (Fig. 6).
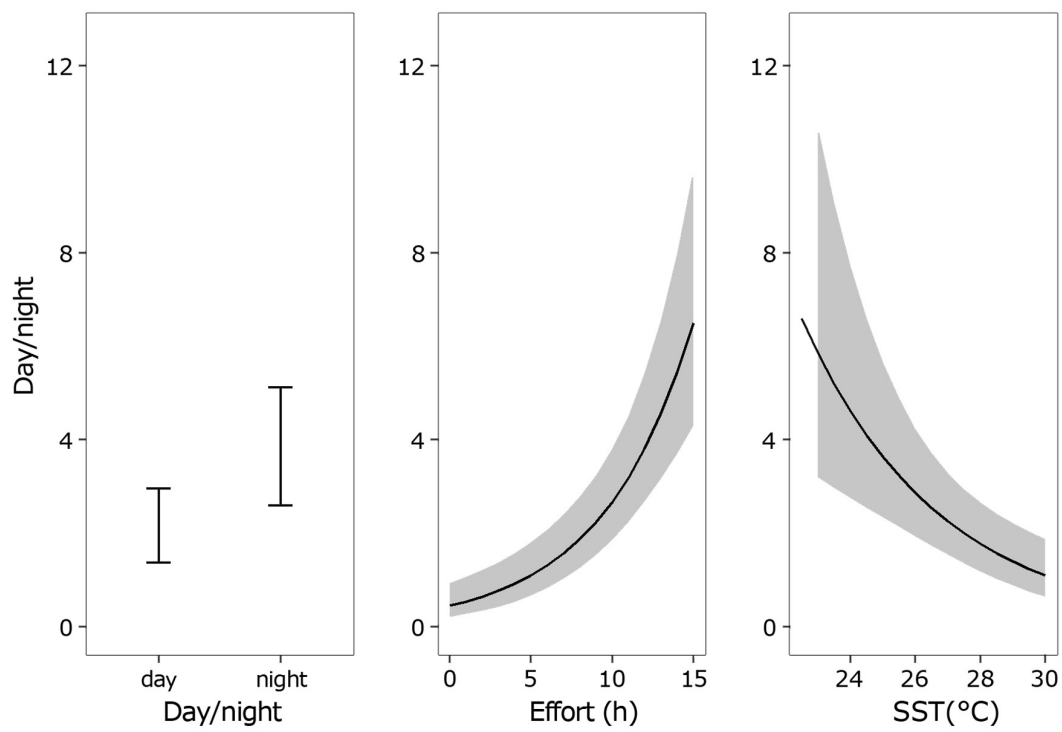

Figure 6. Visual representation of the generalised linear mixed effect model of encounters in relation to day or night, effort (h) and sea surface temperature (SST) / Representación gráfica del modelo generalizado lineal mixto de los encuentros en función del día o la noche, del esfuerzo (h) y la temperatura superficial del mar (SST)

Table 2. Forward model selection of generalised linear mixed-effect model (glmer) / Selección de modelo en adelante del modelo lineal generalizado de efectos mixtos (glmer)

\begin{tabular}{|c|c|c|c|c|c|c|}
\hline Model & Formula & K & $\mathrm{AICc}$ & $\begin{array}{l}\text { Delta } \\
\text { AICc }\end{array}$ & $\begin{array}{l}\mathrm{AICc} \\
\mathrm{Wt}\end{array}$ & LL \\
\hline $\bmod 01$ & encounter $\sim 1+(1 \mid$ month_campaign $)$ & 2 & 204.16 & 63.09 & 0.00 & -99.88 \\
\hline $\bmod 02$ & encounter $\sim$ day/night $+(1 \mid$ month_campaign $)$ & 3 & 191.03 & 49.96 & 0.00 & -92.10 \\
\hline $\bmod 03$ & encounter $\sim$ SST + (1 | month_campaign $)$ & 3 & 193.48 & 52.41 & 0.00 & -93.33 \\
\hline $\bmod 04$ & encounter $\sim$ effort + (1 | month_campaign $)$ & 3 & 155.45 & 14.38 & 0.00 & -74.31 \\
\hline $\bmod 05$ & encounter $\sim$ day/night + SST $+(1 \mid$ month_campaign $)$ & 4 & 182.58 & 41.51 & 0.00 & -86.58 \\
\hline $\bmod 06$ & encounter $\sim$ day/night + effort $+(1 \mid$ month_campaign $)$ & 4 & 146.71 & 5.65 & 0.03 & -68.64 \\
\hline $\bmod 07$ & encounter $\sim$ SST + effort + (1| month_campaign $)$ & 4 & 149.17 & 8.10 & 0.01 & -69.87 \\
\hline $\bmod 08^{*}$ & encounter $\sim$ day/night + SST + effort $+(1 \mid$ month_campaign $)$ & 5 & 141.07 & 0.00 & 0.56 & -64.42 \\
\hline $\bmod 09$ & encounter $\sim$ day $/$ night $*$ effort + SST $+(1 \mid$ month_campaign $)$ & 6 & 144.07 & 3.00 & 0.13 & -64.42 \\
\hline $\bmod 10$ & encounter $\sim$ day/night + effort $*$ SST $+(1 \mid$ month_campaign $)$ & 6 & 142.68 & 1.61 & 0.25 & -63.72 \\
\hline $\bmod 11$ & encounter $\sim$ day/night $*$ effort $*$ SST $+(1 \mid$ month_campaign $)$ & 9 & 148.58 & 7.51 & 0.01 & -61.38 \\
\hline
\end{tabular}

$\mathrm{K}$ parameters, $\mathrm{AICc}=\mathrm{Akaike}$ Information Criterion with a correction for small sample size,

*delta AICc to selected model, AICc weight (Wt), LL: log-likelihood, SST: sea surface temperature 
On an hourly scale, both in 'Jun-Jul' and in 'Sep-Nov' detections were recorded continuously, except for two hours (05:00 and 09:00 h) during 'Sep-Nov' (Fig. 7).

The effort of the boat-based surveys was $554.6 \mathrm{~km}$ and $65 \mathrm{~h}$. Bottlenose dolphins were sighted during 11 out of 16 trips (Fig. 8). Fifteen bottlenose dolphin sightings occurred in the channel and inner parts of the lagoon while three groups were sighted in the outer part of the lagoon. Simultaneous sightings and audio recordings confirmed that whistles came from bottlenose dolphins.

\section{Discussion}

The bottlenose dolphin (Tursiops truncatus) was the only odontocete species that was sighted during 16 experimental boat trips planned to deploy and retrieve acoustic equipment in the entrance to Ensenada de La Paz, which confirmed visual studies since the late 1980s (Acevedo 1991b, Salinas-Zacarías 2005, Medina-Marcín 2010). Due to the inhomogeneous bathymetry north of the station -where the sand bank is located- whistles originated most probably from within the channel and not from the bay and were thus from bottlenose dolphins.

Table 3. Selected generalised linear mixed effects model / Modelo de efectos mixtos lineales generalizados seleccionado

\begin{tabular}{lcccccccc}
\hline & Estimate & CI low & CI high & z value & df & Cohen's d & CI low & CI high \\
\hline Intercept & 5.77 & 2.39 & 9.15 & 3.35 & 28 & 1.266 & 0.525 & 2.006 \\
Day/night & 0.6 & 0.24 & 0.95 & 3.3 & 28 & 1.248 & 0.507 & 1.989 \\
SST & -0.24 & -0.36 & -0.12 & -3.85 & 28 & -1.454 & -2.195 & -0.713 \\
Effort & 0.18 & 0.12 & 0.23 & 6.11 & 28 & 2.309 & 1.568 & 3.050 \\
\hline
\end{tabular}

CI: confidence interval, df: degree of freedom, effect size (Cohen's d), CI of effect size, $\mathrm{SST}=$ sea surface temperature

a)

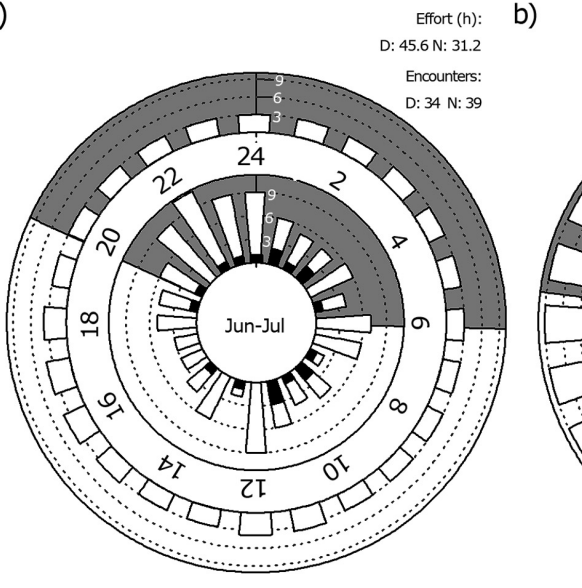

- Long acoustic encounters b)

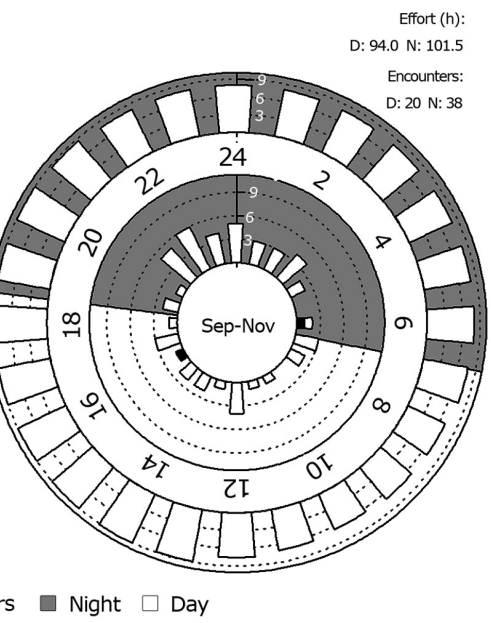

Figure 7. Circular plots of cumulative hourly effort (outer circle) and acoustic encounters of bottlenose dolphins (inner circle) in the entrance to Ensenada de la Paz, Baja California Sur, Mexico during 'Jun-Jul' (a) and 'Sep-Nov' (b) / Gráficas circulares con el esfuerzo (circulo exterior) y los encuentros de delfines nariz de botella (circulo interior) cumulativo por hora en la entrada a la Ensenada de La Paz en 'Jun-Jul' (a) y 'Sep-Nov' (b) 
a)

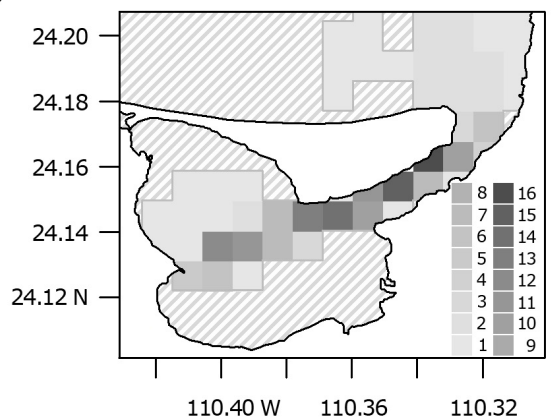

b)

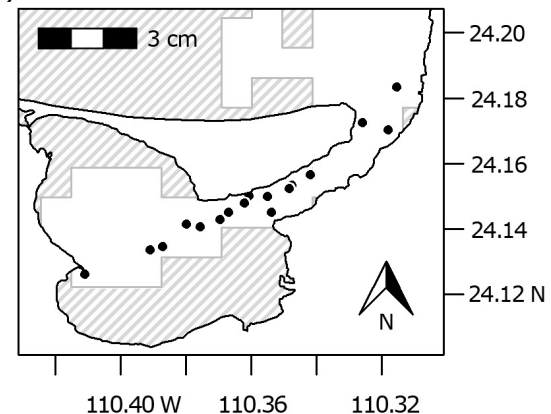

c)

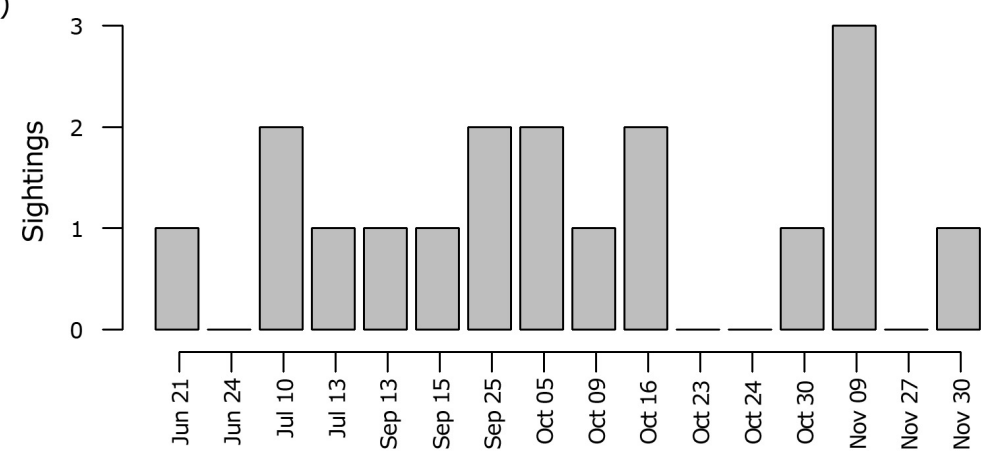

Figure 8. Effort in km (a), location (b) and date (c) of sightings of bottlenose dolphins during surveys to Ensenada de La Paz, Baja California Sur, Mexico / Esfuerzo (a), localidad (b) y fecha (c) de avistamientos de delfines nariz de botella durante las prospecciones en la Ensenada de La Paz, Baja California Sur, México

Statistical tests displayed that differences in acoustic activity existed between 'Jun-Jul' and 'Sep-Nov' and day and night but not between hours. Hence, this study concludes that the presence of bottlenose dolphins in the lagoon was continuous and not limited to certain moments of the day (presence during all hours of the day and during $23.0 \%$ of all hours).

Long acoustic encounters (ED $>10 \mathrm{~min} ; 0.04 \%$ of overall recordings) might indicate animals staying in the area for a specific activity, such as group foraging or nursing (Therrien et al. 2012, Hodge et al. 2013, King \& Janik 2015, Heiler et al. 2016). In contrast, short acoustic encounters that represented $84.2 \%$ of all the acoustic encounters indicated animals travelling ( 0.01 of overall recordings), which is consistent with frequent observations of bottlenose dolphins entering or leaving the lagoon (Marcín-Medina 1997, 2010 and this study). Due to their typical swimming routes along the shoreline and sandbank (Acevedo 1991b, Marcín-Medina 1997, 2010), it was possible that animals recorded were entering or leaving the channel. Observational data support this assumption because bottlenose dolphins were sighted mostly within the inner parts of the lagoon (15 out of 18 sightings); hence, they needed to pass the location of the hydrophone to enter and leave the area. Additional studies with more sampling points might be required to confirm this assumption.
A higher proportion of acoustic encounters found in 'Jun-Jul' compared to 'Sep-Nov' confirmed previous visual studies stating that bottlenose dolphins in Ensenada de La Paz and adjacent waters had lower abundance estimates during winter-spring and higher ones from May to August. Previous studies were based on visual boat-based linetransect surveys (Salvadeo et al. 2009, Pardo et al. 2013) or used the focal follow method (Salinas-Zacarias 2005, Marcín-Medina 1997, 2010). In this study, the use of acoustic techniques added to the knowledge obtained from visual studies since it provided a better temporal coverage, including day and night detections. The inherent lower spatial coverage of moored acoustics detection systems has been overcome by integrating over a longer time and by strategic positioning (e.g., Elliott et al. 2011, La Manna et al. 2014).

The collected acoustical data were adequate to prove continuous day/night presence of bottlenose dolphins during all eight deployments. Former studies showed that bottlenose dolphins used Ensenada de La Paz for feeding, socialising, resting, and nursing (Acevedo 1991b, MarcínMedina 1997, 2010), which were studies based only on diurnal sightings and did not consider the night time use of this area. In this study, whistles provided an evidence of continuous presence during day and night. Furthermore, the analyses per hour showed that there was not a specific 
moment when bottlenose dolphins were present or absent. This is an indication of continuous presence, independently if overall detections were high as in 'Jun-Jul' or low as in 'Sep- Nov'.

This study highlighted that one acoustic monitoring station that recorded omnidirectional whistles at the entrance of a lagoon was enough to confirm the continuous presence of bottlenose dolphins in Ensenada de La Paz. Earlier published data showed the importance of this area for socialising and nursing during daylight hours (Acevedo 1991b, Marcín-Medina 1997, 2010). This study emphasised how acoustic monitoring may address continuous presence and night-time occurrence. In future studies, the recordings with echolocation clicks might be included as they may provide not only evidence of feeding but also socialising as whistles do. This difference in behaviour related context means different dolphin detection patterns for both signals (Hodge et al. 2013, Baumann-Pickering et al. 2015, Caruso et al. 2017). Finally, future studies should monitor these resident bottlenose dolphins as putative "environmental sentinels" since they are crucial to assess the environmental quality of Ensenada de La Paz. This strategy may help to improve management and conservation plans, as required by Mexican environmental regulations (DOF 19-012018 ${ }^{10}$; NOM-059-SEMARNAT-2010 ${ }^{11}$ ).

\section{ACKNOWLEDGEMENTS}

The authors thank Raul Martinez Rincon for granting space during his surveys to Balandra lagoon and to the technical staff of the Centro de Investigaciones Biológicas del Noroeste (CIBNOR), especially to Captain Mario Cota. Further thanks go to Michelle Gelippi, who helped during field work and provided valuable comments in the manuscript; to the anonymous reviewers and Diana Fischer for their comments and corrections. This study was funded by CIBNOR. The author M.FW.G. would like to thank the National Council of Science and Technology of Mexico (CONACYT) for scholarship grant (number: 616366).

\section{LITERATURE CITED}

Acevedo A. 1991a. Interactions between boats and bottlenose dolphins, Tursiops truncatus in the entrance to Ensenada de La Paz, Mexico. Aquatic Mammals 17(3): 120-124.

Acevedo A. 1991b. Behaviour and movements of bottlenose dolphins, Tursiops truncatus, in the entrance to Ensenada De La Paz, Mexico. Aquatic Mammals 17(3): 137-147.

Altherr S \& N Hodgins. 2018. Small cetaceans, big problems A global review of the impacts of hunting on small whales, dolphins and porpoises, $70 \mathrm{pp}$. Pro Wildlife, Animal Welfare Institute \& Whale and Dolphin Conservation, Washington, Munich \& Brookfield House.

Au WWL, KJ Benoit-Bird \& RA Kastelein. 2007. Modeling the detection range of fish by echolocating bottlenose dolphins and harbor porpoises. Journal of the Acoustical Society of America 121(6): 3954-3962.

Au WWL, G Giorli, J Chen, A Copeland, M Lammers, M Richlen, S Jarvis, R Morrissey, D Moretti \& H Klinck. 2013. Nighttime foraging by deep diving echolocating odontocetes off the Hawaiian Islands of Kauai and Ni'ihau as determined by passive acoustic monitors. The Journal of the Acoustical Society of America 133(5): 3119-3127.

Baumann-Pickering S, MA Roch, SM Wiggins, HU Schnitzler \& JA Hildebrand. 2015. Acoustic behavior of melon-headed whales varies on a diel cycle. Behavioral Ecology and Sociobiology 69(9): 1553-1563.

Bazúa-Duran C \& A Herrera-Hernández. 2007. Bottlenose dolphin (Tursiops truncatus) phonations: How recordings and usage are related. Proceedings of the Institute of Acoustics 29(3): 51-54.

Benoit-Bird KJ \& WWL Au. 2003. Prey dynamics affect foraging by a pelagic predator (Stella longirostris) over a range of spatial and temporal scales. Behavioral Ecology and Sociobiology 53: 364-373.

Bossart GD. 2011. Marine mammals as sentinel species for oceans and human health. Veterinary Pathology 48(3): 676-690.

BSH. 2013. Standard untersuchung der auswirkungen von offshore-windenergieanlagen auf die meeresumwelt (StUK4), 85 pp. Bundesamt für Seeschifffahrt und Hydrographie (BSH), Hamburg / Rostock.

Buckland ST, D Anderson, K Burnham, J Laake, L Thomas \& D Borchers. 2001. Introduction to distance sampling: estimating abundance of biological populations, $432 \mathrm{pp}$. Oxford University Press, Oxford.

\footnotetext{
${ }^{10}$ Ley General de Vida Silvestre. Nueva Ley publicada en el Diario Oficial de la Federación el 3 de julio de 2000. Última reforma publicada DOF 1901-2018. <http://www.diputados.gob.mx/LeyesBiblio/pdf/146_190118.pdf>

${ }^{11}$ NORMA Oficial Mexicana. 2010. Protección ambiental-especies nativas de México de flora y fauna silvestres-categorías de riesgo y especificaciones para su inclusión, exclusión o cambio-lista de especies en riesgo. NOM-059-SEMARNAT-2010. <https://www.gob.mx/profepa/documentos/normaoficial-mexicana-nom-059-semarnat-2010>
} 
Bustamante O, S Beristain \& E Romero-Vivas. 2017. Calibración de un hidrófono de bajo costo en el rango sónico mediante una computadora personal utilizando el método de reciprocidad. En: $23^{\circ}$ Congreso Internacional Mexicano de Acústica, pp. 157-168, Centro de Convenciones del Gran Hotel Xalapa, Veracruz, México, miércoles 8 al viernes 10 de noviembre de 2017.

Carlström J. 2005. Diel variation in echolocation behavior of wild harbor porpoises. Marine Mammal Science 21(1): $1-12$.

Caruso F, G Alonge, G Bellia, E De Domenico, $R$ Grammauta, G Larosa, S Mazzola, G Riccobene, G Pavan, E Papale, C Pellegrino, S Pulvirenti, V Sciacca, F Simeone, F Speziale, S Viola \& G Buscaino. 2017. Long-term monitoring of dolphin biosonar activity in deep pelagic waters of the Mediterranean Sea. Scientific Reports 7(1): 1-12.

Castellote M, JM Brotons, C Chicote, M Gazo \& M Cerdà. 2015. Long-term acoustic monitoring of bottlenose dolphins, Tursiops truncatus, in marine protected areas in the Spanish Mediterranean Sea. Ocean \& Coastal Management 113: 54-66.

Elliott RG, SM Dawson \& S Henderson. 2011. Acoustic monitoring of habitat use by bottlenose dolphins in Doubtful Sound, New Zealand. New Zealand Journal of Marine and Freshwater Research 45(4): 637-649.

Fury CA \& PL Harrison. 2011. Seasonal variation and tidal influences on estuarine use by bottlenose dolphins (Tursiops aduncus). Estuarine, Coastal and Shelf Science 93(4): 389-395.

Hammerschlag N, MR Heithaus \& JE Serafy. 2010. Influence of predation risk and food supply on nocturnal fish foraging distributions along a mangrove-seagrass ecotone. Marine Ecology Progress Series 414: 223-235.

Heiler J, SH Elwen, HJ Kriesell \& G Gridley. 2016. Changes in bottlenose dolphin whistle parameters related to vessel presence, surface behaviour and group composition. Animal Behaviour 117: 167-177.

Hodge LEW, JT Bell, A Kumar \& AJ Read. 2013. The influence of habitat and time of day on the occurrence of odontocete vocalizations in Onslow Bay, North Carolina. Marine Mammal Science 29(4): E411-E427.

Hoyt E. 2012. Marine protected areas for whales, dolphins and porpoises: A world handbook for cetacean habitat conservation, $512 \mathrm{pp}$. Routledge, London.

Huber PJ. 1981. Robust statistics, 308 pp, John Wiley \& Sons, New York.

Janik VM \& LS Sayigh. 2013. Communication in bottlenose dolphins: 50 years of signature whistle research. Journal of Comparative Physiology A: Neuroethology, Sensory, Neural, and Behavioral Physiology 199(6): 479-489.

Jensen FH, L Bejder, M Wahlberg \& PT Madsen. 2009. Biosonar adjustments to target range of echolocating bottlenose dolphins (Tursiops sp.) in the wild. The Journal of Experimental Biology 212(8): 1078-1086.

Jensen FH, K Beedholm, M Wahlberg, L Bejder \& PT Madsen. 2012. Estimated communication range and energetic cost of bottlenose dolphin whistles in a tropical habitat. Journal of the Acoustical Society of America 131(1): 582-592.
Joy K, J Hamilton \& I Babb. 2012. Simple hydrophone design, $15 \mathrm{pp}$. COSEE TEK, University of Connecticut, Groton. <http://www.coseetek.net/files/COSEETEK/ hydrophone_build_v3.pdf $>$

King SL \& VM Janik. 2015. Come dine with me: foodassociated social signalling in wild bottlenose dolphins (Tursiops truncatus). Animal Cognition 18(4): 969-974.

La Manna G, M Manghi \& G Sarà. 2014. Monitoring the habitat use of common bottlenose dolphins (Tursiops truncatus) using passive acoustics in a Mediterranean marine protected area. Mediterranean Marine Science 15(2): 327-337.

López-Rasgado FJ, SZ Herzka, P Del-Monte-Luna, E Serviere-Zaragoza, EF Balart \& SE Lluch-Cota. 2012. Fish assemblages in three arid mangrove systems of the Gulf of California: Comparing observations from 1980 and 2010. Bulletin of Marine Science 88(4): 919-945.

Mair P \& R Wilcox. 2019. Robust statistical methods in R using the WRS2 package. Behavior Research Methods 55: 1-29.

Marcín-Medina R. 1997. Comportamiento del tursión (Tursiops truncatus Montagu,1821) en la Ensenada de La Paz, Baja California Sur México. Tesis de Maestría, Centro Interdisciplinario de Ciencias Marinas, Instituto Politécnico Nacional, La Paz, 71 pp.

Marcín-Medina R. 2010. Uso del hábitat del tursión (Tursiops truncatus) en relación a factores ambientales y antropogénicos en la Ensenada y sur de la Bahía de La Paz, B.C.S., México. Tesis de Doctorado en Ciencias, Posgrado en Ciencias Marinas y Costeras, Universidad Autónoma de Baja California Sur, La Paz, 133 pp.

May-Collado LJ \& D Wartzok. 2008. A Comparison of bottlenose dolphin whistles in the Atlantic Ocean: Factors promoting whistle variation. Journal of Mammalogy 89(5): $1229-1240$

Oswald JN, J Barlow \& TF Norris. 2003. Acoustic identification of nine delphinid species in the Eastern Tropical Pacific Ocean. Marine Mammal Science 19(1): 20-37.

Pardo MA, N Silverberg, D Gendron, E Beier \& DM Palacios. 2013. Role of environmental seasonality in the turnover of a cetacean community in the southwestern Gulf of California. Marine Ecology Progress Series 487: 245-260.

Rooker JR \& GD Dennis. 1991. Diel, lunar and seasonal changes in a mangrove fish assemblage off southern Puerto Rico. Bulletin of Marine Science 49(3): 684-698.

Salinas-Zacarías MA. 2005. Ecología de los tursiones, Tursiops truncatus, en la Bahía de La Paz, B.C.S. Tesis de Doctorado en Ciencias Marinas, Centro Interdisciplinario de Ciencias Marinas, La Paz, 102 pp.

Salvadeo CJ, UA Gómez-Gallardo, D Lluch-Belda \& JR Urbán. 2009. The odontocete community and its environment in the southwestern Gulf of California. Latin American Journal of Aquatic Mammals 7(1-2): 23-32.

Therrien SC, JA Thomas, RE Therrien \& R Stacey. 2012 Time of day and social change affect underwater sound production by bottlenose dolphins (Tursiops truncatus) at the Brookfield Zoo. Aquatic Mammals 38(1): 65-75. 
Todd VLG, IB Todd, JC Gardiner, ECN Morrin, NA Macpherson, NA Dimarzio \& F Thomsen. 2015. A review of impacts of marine dredging activities on marine mammals. ICES Journal of Marine Science 72(2): 328-340.

Torres LG \& AJ Read. 2009. Where to catch a fish? The influence of foraging tactics on the ecology of bottlenose dolphins (Tursiops truncatus) in Florida Bay, Florida. Marine Mammal Science 25(4): 797-815.

Verdugo-Díaz G, SA Verdugo-Moreno, DE RodríguezOlachea \& ER Ojeda-Ramos. 2017. Estructura de la comunidad de avifauna asociada al manglar El Conchalito, BCS, México bajo diferentes condiciones de marea. CICIMAR Oceánides 32(1): 1-9.

Versluis M, B Schmitz, A von Heydt \& D Lohse. 2000. How snapping shrimp snap: Through cavitating bubbles. Science 289: 2114-2117.
Wang ZT, PE Nachtigall, T Akamatsu, KX Wang, YP Wu, JC Liu, GQ Duan, HJ Cao \& D Wang. 2015. Passive acoustic monitoring the diel, lunar, seasonal and tidal patterns in the biosonar activity of the Indo-Pacific humpback dolphins (Sousa chinensis) in the Pearl River Estuary, China. PLoS ONE 10(11): 1-24. <http://doi. org/10.1371/journal.pone.0141807>

Wells RS, HL Rhinehart, LJ Hansen, JC Sweeney, FI Townsend, R Stone, DR Casper, MD Scott, AA Hohn \& TK Rowles. 2004. Bottlenose dolphins as marine ecosystem sentinels: developing a health monitoring system. EcoHealth 1(3): 246-254.

Zapata MJ, SMP Sullivan \& SM Gray. 2019. Artificial lighting at night in estuaries -implications from individuals to ecosystems. Estuaries and Coasts 42(2): 309-330.

Zimmer WMX. 2011. Passive acoustic monitoring of cetaceans, 366 pp. Cambridge University Press, Cambridge.

Recibido el 21 de marzo de 2019 y aceptado el 16 de septiembre de 2020

Editor: Claudia Bustos D. 